\title{
Aktivitas di Sekolah Diliburkan saat Pendemi Covid-19: Bagaimana Pembelajaran yang Dilakukan?
}

\author{
Sukma Wijayanto ${ }^{1}$, Dita Febri Handani ${ }^{2}$, Aditia Eska Wardana $^{1}$, Kun Hisnan Hajron $^{1}$ \\ ${ }^{1}$ Universitas Muhammadiyah Magelang \\ ${ }^{2}$ SD Negeri Cacaban 6 Magelang \\ Sukma.Wijayanto@ummgl.ac.id*
}

\begin{abstract}
This study aims to describe the learning activities carried out at Cacaban 6 Elementary School in Magelang City during the Covid-19 pandemic. This study uses a qualitative descriptive approach to obtain information from informants in learning activities. The informants in the study were the teachers taken as a sample of six people and a school principal. The results obtained from this study indicate that learning activities are carried out in two ways, namely online via the Whatsapp application, Youtube, and Google form and offline or face to face. The findings of this study reinforce the implementation of learning activities policy that must be carried out by utilizing technology during the Covid-19 pandemic. It also strengthens the participation of parents to continue to be involved in the learning process of students, thus requiring them to always be communicative. The findings of this study can be a basis for following up on the policy of learning activities from home and efforts to solve the problem. In addition, this research can be the basis for conducting further studies in relation to learning activities during the pandemic.
\end{abstract}

Key words: Learning from home; Online; Covid-19 Pandemic.

\begin{abstract}
Abstrak. Penelitian ini bertujuan mendeskripsikan pembelajaran yang dilakukan dalam pandemi Covid-19 di SD Negeri Cacaban 6 Kota Magelang. Penelitian menggunakan pendekatan deskriptif kualitatif untuk mendapatkan informasi dalam kegiatan pembelajaran. Informan dalam penelitian sebanyak 6 guru dan kepala sekolah. Hasil yang didapatkan bahwa pembelajaran dilakukan secara daring (wa, youtube, dan google form) dan luring. Temuan penelitian ini menguatkan pelaksanaan pembelajaran pada masa aktivitas libur pandemi covid 19 dalam memanfaatkan teknologi dan mengatasi keterbatasan seperti kurangnya keterlibatan orang tua dalam pembelajaran serta keterbatasan fasilitas serta harus komunikatif dengan orang tua.Temuan penelitian ini dapat menjadi landasan untuk tindak lanjut dalam pembelajaran, dan upaya-upaya pemecahan masalah. Disamping itu penelitian ini dapat menjadi landasan untuk melakukan kajian lebih dalam dalam hubungannya dengan pembelajaran yang dilakukan saat pendemi.
\end{abstract}

Kata kunci: Belajar dari Rumah; Daring; Pendemi COVID-19

\section{Pendahuluan}

Tahun 2020 ditandai dengan mewabahnya virus corona (Covid-19) yang menggemparkan dunia. Wabah Virus Covid-19 telah mewabah hampir di seluruh negara. Awal kemunculan Covid-19 diketahuai dari Wuhan, China kemudian menular di banyak negara. Covid-19 merupakan penyakit baru yang dapat dengan mudah menular dari manusia ke manusia melalui kontak erat dan droplet (Susilo, dkk., 2020). Covid-19 pertama dilaporkan di Indonesia pada tanggal 2 Maret 2020, dan pada tanggal 11 Maret 2020, WHO menetapkan Covid-19 sebagai pandemi (Kementerian Kesehatan Republik 
Indonesia, 2020). Hal tersebut berdampak pada adaya himbauan untuk menjaga jarak fisik dan sosial (social distancing) untuk membatasi penyebaran Covid-19. Surat Edaran Mendikbud RI No 3 Tahun 2020 tentang Pencegahan Covid-19 pada satuan pendidikan memberikan himbuan pada instansi pendikan untuk melakukan pembelajaran di rumah. Kebijakan tersebut merupakan salah satu bentuk upaya dalam rangka meminimalisir penyebaran Covid-19.

Instansi pendidikan dari perguruan tinggi hinga PAUD melakukan pembelajaran dari rumah dengan tujuan meminimalisir penyebaran virus. Sekitar 45 juta siswa di Indonesia tidak dapat melangsungkan pembelajaran di sekolah (Azzahra, 2020). Permasalahan pendemi Covid-19 menjadikan pembelajaran daring menjadi solusi bagi untuk membelajarkan siswa. Pembelajaran daring menjadi pilihan dengan tidak memungkinkannya melakukan pembelajaran secara tatap muka. Pembelajaran daring merupakan pembelajaran yang dilakukan melalui jaringan internet yang tersedia materi dan tugas yang harus dikerjakan (Khusniyah \& Hakim, 2019; Mustofa, Chodzirin, Sayekti, \& Fauzan, 2019). Pembelajaran dengan daring yang dilakukan memberikan kelaluasaan bagi siswa karena tidak terikat ruang dan waktu. Siswa dapat tetap belajar tanpa harus pergi ke ruang kelas, dan pembelajaran dapat dijadwalkan sesuai kesepakatan antara siswa dan guru (Mahnun, 2018). Pembelajaran daring memiliki kelebihan untuk dilakukan dimana dan kapan saja, memiliki cakupan yang luas dan mempermudah penyempurnaan dan penyimpanan materi pembelajaran (Jamaluddin, Ratnasih, Gunawan, \& Paujiah, 2020; Windhiyana, 2020). Beberapa studi mengungkapkan bahwa pembelajran daring dapat meningkatkan kinerja peserta didik,(Windhiyana, 2020). Disamping itu, pemanfaatan media sosial seperti facebook, youtube, instagram dan whatsapp yang digunakan dalam pembelajaran dapat membantu perserta didik untuk belajar dan mengkonstruk pengetahuan (Chen \& Bryer, 2012; Greenhow \& Lewin, 2016; Salehudin, 2020; Seaman, 2013).

Meskipun begitu, permasalahan pendemi Covid-19 berdampak pada kesiapan pelaksanaan belajar di rumah. Persoalan membelajarkan saat ini bukan hanya berkaitan dengan materi apa yang akan diajarkan dan bagaimana mengajarkannya namun juga berkaitan berkaitan dengan permasalahan yang komplek. Tidak hanya kesiapan fasilitas untuk mengakses informasi dan pengetahuan secara online, tapi terkait juga dengan peran sekolah, guru, dan orang tua (Pajarianto, Kadir, Galugu, Sari, \& Februanti, 2020). Tidak semua pendidik dan peserta didik memiliki fasilisitas untuk melakukan pembelajaran daring. Tidak sedikit pembelajaran daring menjadi kurang optimal karena infrastruktur yang digunakan tidak memadai untuk digunakan baik oleh pendidik maupun 
peserta didik \{Formatting Citation\}. Mahalnya fasilitas menjadi kendala dalam pelaksanaan pembelajaran daring menjadi kendala tersendiri dalam pelaksanaan pembelajatan dengan menggunakan kemajuan teknologi sebagai alat melangsungkan pembelajaran (Yoo, Jeong Kim, \& Young Kwon, 2014). Dalam hal ini, sekolah harus menesuaikan pembelajaran yang dilakukan dengan menyesuaikan dengan keadaan dan situasi yang terjadi.

Tuntutan untuk merubah pembelajaran yang semula dilakukan secara tatap muka menjadi ke pembelajaran daring dengan memanfaatkan teknologi secara daring menjadi tantangan sekolah melakukan adaptasi menghadapi persoalan dalam melangsungkan pembelajaran sesuai dengan keadaan. Kompleksitas tantangan dalam pelaksanaan pembelajaran membutuhkan suatu upaya adaptif agar pembelajaran dapat digunakan secara efektif (Fullan, 2011; Hargreaves, 2000). Guru harus memahami dan mampu menggunakan teknologi digital, memprediksi permasalahan, dan strategi yang digunakan untuk memunculkan ide, dalam pembelajaran (AACTE \& P21, 2013; Khusniyah \& Hakim, 2019; Pacific Policy Research Center, 2010). Penyesuaikan dengan situasi, kondisi, dan konteks yang ada menjadi pertimbangan guru bagaimana membelajarkan siswa secara tepat. Tuntutan untuk tetap melangsungkan pembelajaran membuat sekolah memikirkan strategi yang tepat untuk membelajarkan siswa di rumah.

Penelitian tekait dampak covid - 19 terhadap proses pembelajaran telah dilakukan oleh beberapa peneliti diantaranya Pajarianto et al., 2020; Purwanto et al., 2020; Setiawan Rifqi, 2020; dan Dewi, 2020). Berdasarkan beberapa penelitian yang telah dilakukan belum menggambarkan cara yang digunakan guru untuk mengatasi kendala dan keterbatasan pembelajaran daring. Berdasarkan hal tersebut penelitian ini bertujuan mendeskripsikan pelaksanaan pembelajaran daring selama masa pandemic dan mengungkapkan kendala yang dihadapi dan cara yang digunakan untuk mengatasi kendala pembelajaran daring pada masa belajar dirumah pada masa pendemi Covid-19 di SD Negeri Cacaban 6 Magelang.

\section{METODE}

Pendekatan penelitian ini adalah penelitian deskriptif dengan pendekatan kualitatif. Pendekatan kualititatif berusaha menelaah fenomena sosial dalam suasana yang berlangsung secara alamiah dan tidak terkondisi secara eksperimenalis. Penelitian ini merupakan penelitian deskriptif dimana data yang dikumpulkan berupa kata-kata, gambar dan data yang berasal dari hasil wawancara, catatan lapangan, foto, video tape, dokumentasi pribadi, catatan, atau memo (Moleong, 2017) 
Penelitian ditujukan untuk mendeskripsikan fenomena pembelajaran yang berlangsung dalam pendemi Covid-19 di SD Negeri Cacaban 6 Kota magelang. Pengumpulan data dilakukan melalui wawancara yang dilakukan pada 6 guru dan kepa sekolah, obeservasi dan dokumentasi. Data terkumpul dicatat untuk dianalisis menggunakan model analisis interaktif (Miles \& Huberman, 1992). Data yang diperoleh kemudian melakkan reduksi data, penyajian data, dan penarikan kesimpulan. keabsahan data dilakukam dengan triangulasi sumber dan teknik.

\section{Hasil dan Pembahasan}

\section{Pelaksanaan Pembelajatan Di SD Negeri Cacaban 6 Kota Magelang}

Dalam masa darurat bencana Covid-19, sekolah dasar memberlakukan pembelajaran dengan tidak mengumpulkan masa yang dimulai pada 16 maret 2020. Pilihan yang dilakukan adalah dengan melakukan pembelajaran daring. Hal tersebut didasarkan pada Surat Edaran Nomor 4 Tahun 2020 tentang Pelaksanaan Pendidikan dalam Masa Darurat Coronavirus Disease (Covid-19).

Pembelajaran yang dilakukan di SD Negeri Cacaban 6 dilakukan dengan variatif tergantung dari kebutuhan, karakteristik kelas, dan kreatifitas guru. Kepala sekolah mengatakan bahwa untuk melakukan pembelajaran sekolah tidak melakukan kebijakan secara khusus terkait pembelajaran daring. Pembelajaran diserahkan sepenuhnya pada guru untuk proses pembelajaran yang dilakukan. Berikut pembelajaran yang dilakukan di SD Negeri 6 Cacaban Magelang.

Kreativitas dan sikap adaptif guru dipacu dalam memanfaatkan berbagai strategi agar siswa tetap mendapatkan materi pembelajaran dalam melakukan pembelajaran secara daring. Pembelajaran SD Negeri Cacaban 6 dilakukan secara daring (dalam jaringan) melalui whatsapp, google form, dan youtube. Disamping itu pembelajaran juga dilakukan diluar jaringan.

Diantara berbagai sarana yang digunakan dalam pembelajaran daring lebih banyak dengan dilakukan melalui whatsapp. Guru mengatakan bahwa whatsapp merupakan media yang paling efektif digunakan. Guru, siswa, dan orang tua merasa mudah dalam menggunakan aplikasi tersebut. Disamping itu, guru juga lebih mudah melakukan kerjasama dengan orang tua dalam proses belajar siswa. Selain whatsapp, guru juga menggunakan google form dan google classroom. Guru menggunakan aplikasi tersebut untuk memberikan kuis, dan evaluasi.

Pembelajaran daring yang dilakukan dengan menggunakan whatsapp paling mudah, dan efektif untuk dilakukan. whatsapp karena semua orang tua siswa memiliki 
aplikasi tersebut, dan lebih mudah baik guru maupun orang tua sudah terbiasa menggunakan (wawancara guru kelas 6, kepala sekolah, 12 Mei 2020). Hal tersebut menjadi alasan penggunakan whatsapp sebagai sarana yang digunakan sebagai pembelajaran. Guru-guru melakukan berbagai kegiatan pembelajaran malalui whatsapp. Diskusi dalam grup, merekam caramah, dan melakukan diskusi yang dilakukan membagikan video yang didapatkan dari youtube, voice note.

Penggunaan platform lain seperti youtube dan google form juga dilakukan oleh guru disamping whatsapp. Penggunaan video dari youtube diberikan guru sebagai bahan siswa untuk mempelajari materi (wawancara guru kelas 5, 30 Mei 2020). Youtube memungkinkan siswa belajar dari video terkait pembelajaran yang diberikan. Disamping itu, penggunaan google form dilakukakan untuk memberikan kuis dan evaluasi pada siswa. Kuis dan soal evaluasi diberikan melalui grup whatsapp, kemudian siswa mengerjakan (guru kelas 2, guru kelas 3, wawancara, 6 Juni 2020).

Pembelajaran yang dilakukan guru pada masa belajar di rumah dilakukan juga dengan memberikan tugas secara luring, yakni memberikan tugas melalui koordinasi dengan orang tua. Orang tua datang ke sekolah untuk mengambil tugas yang diberikan oleh guru sekaligus memberikan penjelasan terkait tugas yang diberikan. Guru menggunakan cara ini untuk membangun komunikasi antara guru, orang tua, dan siswa. Guru kelas 6 mengetakan (wawancara 6 Juni 2020),

"pemberian tugas yang diambil orang tua itu karena keterbatasan yang dimiliki oleh siswa. Kita tidak selalu bisa melakukan diskusi, tanya jawab atau pebelajaran dengan wa, atau youtube. HP di rumah kadang hanya dimiliki orang tua. Sehingga perlu cara lain. Selain itu, tugas juga diberikan agar komunikasi antara orang tua dan sekolah bisa terjadi. Orang tua terlibat dalam anak belajar di rumah.

Tabel 1. Pembelajaran daring di SD Negeri 6 Cacaban Magelang

\begin{tabular}{|c|c|}
\hline Subjek & Bentuk Pembelajaran \\
\hline Guru Kelas 1 & $\begin{array}{l}\text { 1. Memberikan tugas yang diambil oleh tua ke sekolah. } \\
\text { 2. Melakuan diskusi dan tanya jawab dengan menggunakan whataspp. }\end{array}$ \\
\hline Guru Kelas 2 & $\begin{array}{l}\text { 1. Memberikan tugas yang diambil oleh tua ke sekolah. } \\
\text { 2. Mengirimkan video pembelajran, melakuan diskusi dan tanya jawab } \\
\text { dengan menggunakan whatsapp. }\end{array}$ \\
\hline Guru Kelas 3 & $\begin{array}{l}\text { 1. Membuat kuis dengan google form. } \\
\text { 2. Membagiakan video pembelajaran yang diambil dari youtube, } \\
\text { berdiskusi dan memberikan latihan soal dengan menggunakan } \\
\text { whatspp. } \\
\text { 3. Pemberian dan pengumpulan tugas yang di sekolah. }\end{array}$ \\
\hline Guru Kelas 4 & $\begin{array}{l}\text { 1. Memberikan materi berupa bahan ajar, video dan voice note melalui } \\
\text { whatsapp } \\
\text { 2. Membuat kuis dan penilaian dengan google form. }\end{array}$ \\
\hline Guru Kelas 5 & $\begin{array}{l}\text { 1. Melakukan diskusi, memeberikan materi pembelajaran, video yang } \\
\text { diambil dari youtube, dan memberikan soal melalui whatsapp } \\
\text { 2. Laporan tugas berupa praktik dan proyek dengan bentuk foto dan }\end{array}$ \\
\hline
\end{tabular}


video melalui Whatsapp.

3. Melakukan diskusi malaui Whatsapp.

Guru Kelas $6 \quad$ 1. Memberikan tugas yang diambil oleh tua ke sekolah.

2. Melakukan diskusi, memeberikan materi pembelajaran, video yang diambil dari youtube, dan memberikan soal melalui whatsapp

Bentuk luring (diluar jaringan) digunakan oleh guru sebagai bentuk lain dari pembelajaran daring. Keterbatasan fasilitas yang dimiliki siswa dalam pembelajaran menjadi kendala untuk melangsungkan pembelajaran. Hal tersebut dikatakan guru kelas 1 dan guru kelas 6 bahwa seringkali siswa tidak bisa terlibat dalam pembelajran daring karena tidak memliki gawai atau laptop (wawancara guru kelas 1, guru kelas 6, 12 mei 2020). Hal senada juga disampaikan kepala sekolah (wawancara 12 Mei 2020),

"Diantara kesualitan dalam pembelajaran daring adalah fasilitas siswa, sehingga diperlukan pembelajatan diluar jaringan. Tidak semua siswa memiliki laptop, atau gawai. Sehingga untuk melangsungkan pembelajaran atau memberi penugasan perlu bergantian dengan anggota keluarga yang lain, atau menunggu orang tuanya pulag berkerja.

Fasilitas pembelajaran dalam hal ini adalah laptop, gawai, dan kuota internet internet untuk melangsung pembelajaran. Ketersediaan fasilitas tersebut menjadi kendala dalam pelaksanaan pembelajaran. Hal tersebut dikarenakan tidak sedikit latar belakang ekonomi keluarga siswa yang variatif. Disamping itu, kuota internet yang dimiliki oleh siswa juga terbatas. Jaringan internet yang digunakan membutuhkan biaya tambahan untuk membeli kuota dan guru perlu mempertimbangkan tambahan biaya tersebut dalam melaksanakan pembelajaran (Guru kelas 6, Wawancara, 12 Mei 2020).

Pembelajaran daring dibutuhkan fasilitas yang memadai. Penggunaan internet sangat mahal dan ketersediannya tidak semua siswa dapat menjangkau. Banyak orang tua tidak dapat mencukupi kebutuhan fasilitas dalam pembelajaran daring seperti laptop, tablet, gawai, jaringan, dan biaya tambahan kuota internet (Herliandry \& Suban, 2020; Syah, 2020). Perbedaan latar belakang ekonomi menjadi permasalahn yang menghambat proses pembelajaran yang dilakukan dengan teknologi. Adanya kesenjangan antar siswa memberikan dampak pada kurangnya fasilitas pembelajaran yang dilaksanakan (Purwanto, et al., 2020; Yoo, Jeong Kim, \& Young Kwon, 2014). Tidak semua orang tua dapat memenuhi fasilitas guna pembelajaran daring seperti jaringan (Obiakor \& Adeniran, 2020) dan kuota internet (Jamaluddin et al., 2020). Ketersediaan fasilitas yang dimiliki siswa menjadi kendala untuk dapat melangsungkan belajar di rumah. Siswa yang tidak dapat mengakses informasi berpotensi tertinggal dari siswa lain secara akademis dan 
akan ada kesenjangan akademis dalam pembelajaran selama masa belajar di rumah (Frenette, Frank, \& Deng, 2020).

Selain kendala fasilitas adalah kurangnya keterlibatan orang tua dalam pembelajaran di rumah. Keterlibatan orang tua menjadi kendala dalam pelaksananan pembelajaran dalam sistem belajar yang dilakukan di SD Negeri Cacaban 6. Hal tersebut dikarenakan salah satu kesuksesan belajar di rumah adalah adanya peran orang tua yang berperan aktif dalam kegiatan belajar anak. Kepala sekolah mengatakan, “orang tua kurang dapat memberikan pendampingan pada kegiatan belajar anak. Kurangnya pendampingan tersebut karena orang tua sibuk bekerja. Disamping itu, orang tua juga sering tidak paham pada materi" (wawancara, 12 Mei 2020). Tidak hanya itu, dalam beberapa situasi di temukan orang tua yang mengerjakan tugas yang diberikan guru (wawancara guru kelas 6, 12 Mei 2020). Hal senada juga dikatakan guru kelas 5, bahwa tugas siswa sering dikerjakan oleh orang tua atau saudaranya (wawancara, 30 Mei 2020). Hal ini tentunya menjadi kendala dalam pembelajaran secara daring karena usaha dan tanggung jawab orang tua berperan besar dalam proses mendidik siswa pada masa belajar di rumah (Syah, 2020), serta orang tua berkontribusi besar dalam pencapaian pendidikan bagi anaknya (Cheung \& Pomerantz, 2012; D’Agostino; Gonida \& Cortina, 2014).

Penelitian menguatkan dengan penelitian yang terdahulu disekolah dasar mengenai aktivititas belajar pada masa pandemi covid 19 yang lebih menggambarkan aktivitas belajar pada daring dengan menggunakan beberapa platform seperti Whatsapp, youtube, dan google form yang sebelumnya banyak digambarkan dalam studi literatur (Aji, Dewi, Kristen, \& Wacana, 2020; Arizona, Abidin, \& Rumansyah, 2020; Herliandry \& Suban, 2020; Syah, 2020). Selain itu, temuan penelitian menggambarkan cara yang digunakan guru untuk mengatasi untuk mengatasi kendala dan keterbatasan pembelajaran berbasis daring yang belum banyak diterangkan dalam kajian penelitian sebelumnya (Pajarianto et al., 2020; Purwanto et al., 2020; Setiawan Rifqi, 2020). Penelitian aktivitas pembelajaran menggunakan sistem luring (diluar jaringan) sebagai solusi dalam mengatasi kendala pembelajaran daring serta bertujuan adanya peran aktif dari orang tua. Bentuk pembelajaran luring yang dilakukan oleh guru adalah dengan cara memberikan tugas yang diambil oleh orang tua ke sekolah.

\section{Kesimpulan}

Pelaksanaan pembelajaran dalam masa pendemi Covid-19 yang dilakukan di SD Negeri Cacaban 6 dengan dua cara, secara daring dan luring. Pembelajaran secara daring dilakukan lebih banyak melalui dengan menggunakan whatsapp, youtube, dan google 
form. Dalam pelaksanaan pembelajaran daring, kendala yang dihadapi adalah kurangnya keterlibatan orang tua dalam proses belajar siswa. Kurangnya keterlibatan tersebut dikarenakan kesibukan yang dilakukan oleh orang tua. Disamping itu, ketersediaan fasilitas seperti laptop, tablet, gawai, jaringan internet, dan kuota internet dalam melangsungkan pembelajaran tidak semua dapat dengan dimiliki siswa. Temuan penelitian ini juga memberikan pembelajaran secara luring sebagai upaya mengatasi keterbatasan dan kendala pembelajaran daring. Penelitian ini diharapkan bisa memberikan informasi terkait implementasi belajar di rumah pada masa pendemi yang tengah terjadi di sekolah dasar. Penelitian ini harapannya bisa menjadi rujukan dengan banyaknya celah untuk dikaji dalam penelitian selanjutnya seperti dari sisi kebijakan, guru, orang tua, siswa, pembelajaran, dan penggunaan teknologi.

\section{Daftar Pustaka}

AACTE \& P21. (2013). Teachers for the 21st Century. Education, (September). https://doi.org/10.1787/9789264193864-en

Aji, W., Dewi, F., Kristen, U., \& Wacana, S. (2020). Dampak Covid-19 Terhadap Implementasi Pembelajaran Daring Di Sekolah Dasar. Edukatif: Jurnal IImu Pendidikan, 2(1), 55-61. https://doi.org/https://doi.org/10.31004/edukatif.v2i1.89

Arizona, K., Abidin, Z., \& Rumansyah, R. (2020). Pembelajaran Online Berbasis Proyek Salah Satu Solusi Kegiatan Belajar Mengajar Di Tengah Pandemi Covid-19. Jurnal Ilmiah Profesi Pendidikan, 5(1), 64-70. https://doi.org/10.29303/jipp.v5i1.111

Azzahra, N. F. (2020). Mengkaji Hambatan Pembelajaran Jarak Jauh di Indonesia di Masa Pandemi Covid-19. Cips, 19(2), 1-9.

Chen, B., \& Bryer, T. (2012). Investigating instructional strategies for using social media in formal and informal learning. International Review of Research in Open and Distance Learning. https://doi.org/10.19173/irrodl.v13i1.1027

Cheung, C. S. S., \& Pomerantz, E. M. (2012). Why does parents' involvement enhance children's achievement? The role of parent-oriented motivation. Journal of Educational Psychology. https://doi.org/10.1037/a0027183

D’Agostino, J. V, Hedges, L. V, \& Borman, G. D. (2001). Title I parent-involvment programs: Effects on parenting practices and student achievement. In Title I: Compensatory education at the crossroads.

Dewi, W.A.F. (2020). Dampak Covid-19 Terhadap Implementasi Pembelajaran Daring Di Sekolah Dasar. Edukatif : Jurnal Ilmu Pendidikan. 2(1). 55-61. https://doi.org/10.31004/edukatif.v2i1.89

Frenette, M., Frank, K., \& Deng, Z. (2020). School Closures and the Online Preparedness of Children during the COVID-19 Pandemic Economic Insights School Closures and the Online Preparedness of Children during the COVID-19 Pandemic by Marc Frenette, Kristyn Frank, and Zechuan Deng. (April).

Fullan, M. (2011). Whole system reform for innovative teaching and learning. MicrosoftITL Research (Ed.), Innovative Teaching and Learning Research.

Gonida, E. N., \& Cortina, K. S. (2014). Parental involvement in homework: Relations with parent and student achievement-related motivational beliefs and achievement. 
British Journal of Educational Psychology. https://doi.org/10.1111/bjep.12039

Greenhow, C., \& Lewin, C. (2016). Social media and education: reconceptualizing the boundaries of formal and informal learning. Learning, Media and Technology. https://doi.org/10.1080/17439884.2015.1064954

Hargreaves, A. (2000). Four ages of professionalism and professional learning. Teachers and Teaching: Theory and Practice. https://doi.org/10.1080/713698714

Herliandry, L. D., \& Suban, M. E. (2020). Jurnal Teknologi Pendidikan Pembelajaran Pada Masa Pandemi Covid-19. 22(1), 65-70.

Jamaluddin, D., Ratnasih, T., Gunawan, H., \& Paujiah, E. (2020). Pembelajaran Daring Masa Pandemik Covid-19 Pada Calon Guru : Hambatan, Solusi dan Proyeksi. Karya Tulis IImiah UIN Sunan Gunung Djjati Bandung, 1-10. Retrieved from http://digilib.uinsgd.ac.id/30518/

Kementerian Kesehatan Republik Indonesia. (2020). Pedoman Kesiapsiagaan Menghadapi Coronavirus Disease (COVID-19). Direkorat Jenderal Pencegahan Dan Pengendalian Penyakit.

Khusniyah, N. L., \& Hakim, L. (2019). Efektivitas Pembelajaran Berbasis Daring: Sebuah Bukti Pada Pembelajaran Bahasa Inggris. Jurnal Tatsqif. https://doi.org/10.20414/jtq.v17i1.667

Mahnun, N. (2018). Optimalisasi Pengelolaan Dan Pembelajaran Berbasis Online Pada Lembaga Pendidikan Islam Dalam Mewujudkan World Class University. Indonesian Journal of Islamic Educational Management. https://doi.org/10.24014/ijiem.v1i1.5240

Moleong, L. J. (2017). Metodologi Penelitian Kualitatif (Edisi Revisi). In PT. Remaja Rosda Karya.

Mustofa, M. I., Chodzirin, M., Sayekti, L., \& Fauzan, R. (2019). Formulasi Model Perkuliahan Daring Sebagai Upaya Menekan Disparitas Kualitas Perguruan Tinggi. Walisongo Journal of Information Technology. https://doi.org/10.21580/wjit.2019.1.2.4067

Obiakor, T., \& Adeniran, A. (2020). Covid-19 : Impending Situation Threatens To Deepen Nigeria ' S Education Crisis. Center For The Study Of The Economies Of Africa.

Pacific Policy Research Center. (2010). 21 st Century Skills for Students and Teachers. Research \& Evaluation.

Pajarianto, H., Kadir, A., Galugu, N., Sari, P., \& Februanti, S. (2020). Study from Home in the Middle of the COVID-19 Pandemic : Analysis of Religiosity, Teacher, and Parents Support Against Academic Stress. 12(2), 1791-1807.

Purwanto, A., Pramono, R., Asbari, M., Santoso, P. B., Wijayanti, L. M., Hyun, C. C., \& Putri, R. S. (2020). Studi Eksploratif Dampak Pandemi COVID-19 Terhadap Proses Pembelajaran Online di Sekolah Dasar. Journal of Education, Psychology, and Counseling.

Salehudin, M. (2020). DAMPAK COVID-19 : Guru Mengadopsi Media Sosial Sebagai E Learning Pada Pembelajaran Jarak Jauh Pendahuluan Di Indonesia, pembelajaran jarak jauh ( PJJ) bukanlah sesuatu yang baru, sejak ditetapkannya teknologi dalam Pendidikan dan pembelajaran , upay. Jurnal MUDARRISUNA, 10(1), 1-14.

Seaman, J. (2013). Social Media for Teaching and Learning. Pearson.

Setiawan Rifqi, A. (2020). Lembar Kegiatan Literasi Saintik untuk Pembelajaran Jarak Jauh Topik Penyakit Coronavirus 2019 (COVID-19). Jurnal IImu Pendidikan, 2(1), 28-37. Retrieved from https://edukatif.org/index.php/edukatif/index

Susilo, A., Rumende, C. M., Pitoyo, C. W., Santoso, W. D., Yulianti, M., Sinto, R., ... Cipto, R. 
(2020). Coronavirus Disease 2019 : Tinjauan Literatur Terkini Coronavirus Disease 2019 : Review of Current Literatures. Jurnal Penyakit Dalam Indonesia.

Syah, R. H. (2020). Dampak Covid-19 pada Pendidikan di Indonesia: Sekolah, Keterampilan, dan Proses Pembelajaran. SALAM: Jurnal Sosial Dan Budaya Syar-I, 7(5). https://doi.org/10.15408/sjsbs.v7i5.15314

Windhiyana, E. (2020). Dampak Covid-19 Terhadap Kegiatan Pembelajaran Online Di Perguruan Tinggi Kristen Di Indonesia. Perspektif Ilmu Pendidikan, 34(1), 1-8. https://doi.org/10.21009/pip.341.1

Yoo, S., Jeong Kim, H., \& Young Kwon, S. (2014). Between ideal and reality: A different view on online-learning interaction in a cross-national context. Journal for Multicultural Education. https://doi.org/10.1108/JME-04-2013-0018 